\title{
PENGARUH STRATEGI ARCS (ATTENTION, RELEVANCE, CONFIDENCE AND SATISFACTION) TERHADAP MOTIVASI BELAJAR TIK SISWA DI SMP4 NEGARA
}

\author{
Evy Maya Stefany \\ Teknologi Pembelajaran, Pascasarjana, Universitas Pendidikan Ganesha \\ Singaraja, 81116, Indonesia \\ maya_stefany@ymail.com
}

\begin{abstract}
Abstrak
Penelitian ini bertujuan untuk mendeskripsikan perbedaan motivasi belajar antara siswa yang belajar melalui strategi pembelajaran ARCS dengan siswa yang belajar melalui model pembelajaran langsung, Penelitian ini merupakan eksperimen semu dengan desain pretest-posttest non-equivalent control group design. Populasi dalam penelitian ini adalah seluruh siswa kelas VIII SMPN 4 Negara Tahun Ajaran 2013/2014 yang terdiri dari 8 kelas sebanyak 259 siswa dengan sampel sebanyak 110 siswa yang terdiri dari 2 kelas kelompok eksperimen dan 2 kelas kelompok kontrol. Sampel kelas diambil dengan cara random sampling. Data yang dikumpulkan dalam penelitian ini adalah data motivasi belajar siswa yang dikumpulkan dengan angket motivasi belajar, Kuesioner motivasi belajar berupa pernyataan sebanyak 32 pernyataan dengan 5 pilihan jawaban Data dianalisis menggunakan statistik deskriptif dan mancova. Hasil penelitian menunjukkan bahwa terdapat perbedaan motivasi belajar antara siswa yang belajar melalui strategi pembelajaran ARCS dengan siswa yang belajar melalui model pembelajaran langsung $\left(\mathrm{F}_{\text {hitung }}=248,549 ; \mathrm{p}<0,05\right)$, Disimpulkan bahwa strategi ARCS dapat digunakan untuk meningkatkan motivasi belajar TIK siswa SMP.
\end{abstract}

Kata Kunci: strategi ARCS, motivasi belajar, TIK 


\begin{abstract}
This study aimed to describe the differences in learning motivation between students who learn through teaching strategy ARCS with students who learn through direct instructional model. This study belongs to the quasi experimental design with pretest-posttest non-equivalent control group design. The population in this study were all students of class VIII SMP 4 in the academic year 2013/2014. They are all students of 8 classes consisting of 259 students, with a sample of 110 students consisting of 2 classes experimental group and 2 classes control group. Class samples collected by random sampling. The data collected in this study were data of students motivation collected with learning motivation questionnaire. Learning motivation questionnaire in the form of a statement by 32 statements with 5 answer choices. Data were analyzed using descriptive statistics and Mancova. The results showed that there is a difference between the learning motivation of students who learn through teaching strategy ARCS with students who learn through the learning direct instructional model ( $F$ value $=248.549, p$ <0.05), It was concluded that the ARCS strategies can be used to increase learning motivation TIK of junior high school students.
\end{abstract}

Keywords: ARCS strategies, learning motivation, TIK 


\section{Pendahuluan}

Pendidikan merupakan usaha sadar dan terencana untuk mewujudkan suasana dan proses pembelajaran agar siswa secara aktif mengembangkan potensi yang ada dalam dirinya. Pendidikan memiliki peranan penting dalam upaya menciptakan kehidupan bangsa yang cerdas, damai, terbuka, dan demokratis. Pembaharuan pendidikan harus selalu dilakukan untuk meningkatkan kualitas pendidikan nasional. Kemajuan suatu bangsa hanya dapat di capai melalui penataan pendidikan yang baik. Menurut Degeng (2001) pendidikan di Indonesia selalu mendapatkan sorotan yang sangat tajam berkaitan dengan tuntutan untuk menghasilkan sumber daya manusia yang berkualitas yang mampu menghadapi perkembangan ilmu pengetahuan dan teknologi. Upaya peningkatan mutu pendidikan diharapkan mampu meningkatkan harkat dan martabat manusia Indonesia.

Pembelajaran pada dasarnya merupakan proses komunikasi antara guru dan siswa serta upaya guru untuk membantu siswa melakukan kegiatan belajar. Pembelajaran merupakan sesuatu yang dilakukan oleh siswa, bukan di buat untuk siswa. Tujuan pembelajaran yaitu terwujudnya efisiensi dan efektifitas kegiatan belajar yang dilakukan siswa. Seorang siswa akan dapat mengikuti pembelajaran dengan baik dan mencapai hasil belajar yang optimal, apabila di dukung oleh kondisi lingkungan belajar yang memadai dan memilih pendekatan yang sesuai dengan karakteristik siswa. Dalam kegiatan pembelajaran, siswa sendirilah yang aktif membangun pengetahuannya. Hal tersebut sejalan dengan paradigma pendidikan yang merubah orientasi pembelajaran dari pembelajaran yang berpusat pada guru (teacher centered) menuju pada pembelajaran yang berpusat pada siswa (student centered).
Kualitas dan keberhasilan pembelajaran sangat dipengaruhi oleh kemampuan dan ketepatan guru dalam memilih dan menggunakan model pembelajaran (Solihatin \& Raharjo, 2007). Guru di tuntut untuk menggunakan model yang menarik dan menyenangkan agar siswa tidak merasa bosan dan dapat meningkatnya motivasi belajar sesuai dengan karakteristik siswa. Guru juga harus menggunakan model pembelajaran yang dapat melibatkan siswa untuk dapat berpikir kritis, berpikir kreatif, membuat keputusan dan memecahkan masalah. Kemampuan berpikir kreatif merupakan salah satu modal dasar yang harus dimiliki oleh siswa untuk menghadapi persaingan di era globalisasi saat ini. Pentingnya kemampuan berpikir kreatif untuk dikembangkan juga tercermin pada tujuan pendidikan nasional UU Nomor 20 Tahun 2003 tentang Sisdiknas pasal 3 yaitu berkembangnya potensi siswa agar menjadi manusia yang beriman dan bertaqwa kepada Tuhan Yang Maha Esa, berakhlak mulia, sehat, berilmu, cakap, kreatif, mandiri, dan menjadi warga negara yang demokratis serta bertanggung jawab. Dengan demikian, kemampuan berpikir kreatif siswa dalam pembelajaran perlu dikembangkan untuk mencapai tujuan pendidikan nasional. Kemampuan berpikir kreatif membentuk siswa yang mampu mengungkapkan dan mengelaborasi gagasan orisinil untuk pemecahan masalah.

Berdasarkan hasil observasi yang dilakukan di SMP Negeri 4 Negara dan hasil wawancara dengan guru TIK kelas VIII, terungkap bahwa pada pembelajaran Teknologi Informasi dan Komunikasi (TIK) khususnya pada pokok bahasan Perangkat Lunak Pengolah Angka perlu diterapkan model pembelajaran inovatif yang dapat meningkatkan motivasi belajar. Karena berdasarkan observasi, diketahui bahwa pada proses pembelajaran berlangsung guru menggunakan metode mengajar tanpa mengembangkan 
kemampuan berpikir kreatif siswa. Guru menganggap siswa yang datang dan duduk di kelas tidak membawa pengalaman atau pengetahuan. Hal ini dibuktikan ketika memasuki ruangan kelas, guru langsung menjelaskan materi pelajaran tanpa mempertimbangkan pengetahuan awal siswa. Dalam proses pembelajaran, guru monoton hanya menjelaskan inti materi kemudian siswa menjawab soal-soal yang terdapat dalam buku LKS. Apabila materi pelajaran terkait dengan praktik yang harus dilakukan menggunakan komputer, guru memberikan soal praktik yang sama untuk semua siswa kemudian mengumpulkan hasil karya siswa dalam sebuah file, tanpa melihat bagaimana proses siswa dalam mengerjakan soal tersebut. Minimnya jumlah komputer yang terdapat dalam laboratorium, membuat guru menerapkan sistem rolling dalam pembelajaran TIK, yaitu sebagian siswa berada di dalam kelas dan sebagian lagi berada di dalam laboratorium komputer. Ini menyebabkan banyak waktu yang terbuang percuma, serta pengawasan aktivitas siswa di dalam kelas yang tidak dapat dikendalikan oleh guru. Penerapan metode tersebut di dalam proses pembelajaran di nilai kurang tepat untuk meningkatkan motivasi belajar. Selama ini siswa hanya menerima apa yang diberikan oleh guru yang menggunakan satu sumber berupa buku LKS tanpa menggunakan sumber belajar lain, akibatnya siswa mengalami kesulitan dalam menyerap pengetahuan yang diberikan.

Kondisi pembelajaran seperti itu berdampak pada rendahnya kualitas pembelajaran, yang berimplikasi pada peran siswa dalam proses pembelajaran masih dirasakan kurang. Hal ini disebabkan siswa kurang memiliki rasa percaya diri dalam proses pembelajaran di kelas, siswa menjadi tidak mandiri, tidak disiplin dan kurang bertanggung jawab dalam mengerjakan tugas-tugas yang diberikan oleh guru sehingga siswa kurang mempunyai semangat dalam mengikuti pembelajaran di kelas, kurang termotivasi untuk mendapatkan hasil belajar yang maksimal dan kurang dapat mengembangkan potensi yang dimilikinya dalam kegiatan belajar.

Proses pembelajaran tersebut berakibat pada nilai rata-rata hasil belajar siswa semester genap terutama pada pokok bahasan Perangkat Lunak Pengolah Angka. Nilai tersebut memang masih berada di bawah KKM (Kriteria Ketuntasan Minimal) yang ditentukan yaitu 70, sehingga hasilnya belum maksimal dan memuaskan. Perbaikan kualitas sekolah dan kualitas pembelajaran di anggap perlu untuk dilakukan. Guru sebagai fasilitator harus mampu memberikan pelayanan kepada setiap siswa agar mereka dapat berkembang secara maksimal, sesuai dengan potensi yang dimiliki dan mampu mewujudkan peluang untuk berprestasi serta memecahkan permasalahan dalam belajar. Fakta tersebut mendorong diperlukannya suatu strategi pembelajaran yang mampu meningkatkan motivasi belajar siswa sehingga dapat meningkatkan hasil belajar siswa pada mata pelajaran TIK.

Solusi untuk menghindari pembelajaran TIK yang tidak efektif adalah dengan mengajukan gagasan penerapan model pembelajaran yang dapat meningkatkan motivasi belajar serta dapat mengembangkan potensi siswa agar berani menghadapi masalah yang dihadapi tanpa merasa tertekan, mau dan mampu mengembangkan diri sehingga berakibat pada peningkatan hasil belajar siswa. Strategi pembelajaran ARCS merupakan pembelajaran yang dikembangkan sebagai salah satu alternatif yang dapat digunakan oleh guru sebagai dasar melaksanakan kegiatan belajar dengan baik.

Strategi pembelajaran ARCS dikembangkan atas dasar teori-teori dan pengalaman nyata instruktur sehingga mampu membangkitkan semangat belajar 
siswa secara optimal dengan memotivasi diri siswa sehingga didapatkan hasil belajar yang optimal. Menurut Keller (1987) pembelajaran berbasis ARCS merupakan suatu bentuk pendekatan pemecahan masalah untuk merancang aspek motivasi serta lingkungan belajar dalam mendorong dan mempertahankan motivasi siswa untuk belajar. Model pembelajaran ini berkaitan erat dengan motivasi siswa terutama motivasi untuk memperoleh pengetahuan baru.

Motivasi sangat penting dalam belajar karena motivasi dapat mendorong siswa mempersepsi informasi dalam bahan ajar (Depdiknas, 2005). Sebaik apa pun rancangan bahan ajar, jika siswa tidak termotivasi untuk belajar maka tidak akan terjadi peristiwa belajar karena siswa tidak akan mempersepsi informasi dalam bahan ajar tersebut. Sebagai upaya meningkatkan motivasi guna meningkatkan hasil belajar siswa khususnya pada mata pelajaran TIK, maka penerapan strategi pembelajaran ARCS efektif dipergunakan karena strategi pembelajaran ARCS ini disesuaikan dengan kebutuhan ataupun minat siswa.

Strategi pembelajaran ARCS memuat empat komponen yang merupakan satu kesatuan yang diperlukan dalam kegiatan pembelajaran, yaitu membangkitkan dan memperhatikan perhatian siswa selama pembelajaran (Attention), menggunakan materi pelajaran yang ada relevansinya dengan kehidupan siswa (Relevance), menanamkan rasa yakin dan percaya diri siswa (Confidence), dan menumbuhkan rasa puas pada siswa terhadap pembelajaran (Satisfaction). Kegiatan pembelajaran dengan menerapkan strategi ARCS diawali dengan menumbuhkan perhatian dan motivasi siswa, dengan cara menggali pemahaman siswa menggunakan media pembelajaran yang menarik dan sesuai dengan karakteristik materi pelajaran, serta melibatkan siswa secara aktif dengan memberikan kesempatan siswa untuk bertanya. Selanjutnya menyesuaikan antara materi pembelajaran yang disajikan dengan pengalaman belajar siswa. Berdasarkan keterkaitan atau kesesuaian ini sehingga dapat menumbuhkan motivasi belajar di dalam diri siswa karena siswa merasa bahwa materi pelajaran yang disajikan mempunyai manfaat langsung secara pribadi dalam kehidupan siswa. Motivasi siswa akan bangkit dan berkembang apabila mereka merasakan bahwa apa yang dipelajari itu memenuhi kebutuhan pribadi, bermanfaat serta sesuai dengan nilai yang diyakini atau dipegangnya. Kemudian membangkitkan kesadaran yang kuat dalam proses pembelajaran dengan mengajak siswa memecahkan masalahmasalah sehingga nantinya mampu menumbuhkan rasa percaya diri dan kepuasan siswa. Sebagai bentuk pengakuan atas usaha yang dilakukan siswa, maka siswa diberikan reinforcement berupa penguatan.

Berdasarkan penelitian yang telah dilakukan oleh Abdullah dan Fatimah (2013) bahwa pembelajaran yang menerapkan model pembelajaran langsung dengan strategi motivasi ARCS berpengaruh positif terhadap hasil belajar siswa. Strategi ARCS juga dapat membantu meningkatkan motivasi dan aktivitas siswa dalam belajar sehingga dapat menyelesaikan soal-soal dengan baik dan hasil belajar siswa dapat meningkat.

Motivasi dalam belajar dapat menumbuhkan hasrat dan keinginan untuk belajar dan lebih bermakna. Kegiatan pembelajaran yang telah dipersiapkan guru diharapkan dapat berjalan sesuai dengan apa yang telah direncanakan dan tujuan yang ingin di capai. Salah satu tujuan pembelajaran tersebut adalah adanya perubahan tingkah laku yang berupa sikap ilmiah siswa dan peningkatan hasil belajar. Siswa yang memiliki motivasi tinggi dalam belajar memungkinkan untuk memperoleh hasil belajar yang tinggi, artinya semakin tinggi motivasi, usaha dan 
upaya yang dilakukan, maka semakin tinggi hasil belajar yang diperolehnya (Hamdu \& Agustin, 2011).

Berdasarkan analisa tersebut, dapat diketahui bahwa kualitas proses pembelajaran TIK perlu dioptimalisasikan, utamanya dalam peningkatan motivasi belajar serta pencapaian hasil belajar siswa. Penerapan secara interaktif strategi pembelajaran di duga dapat memberikan sumbangan dalam meningkatkan motivasi belajar siswa.

\section{Metode Penelitian}

Penelitian ini bertujuan untuk menguji pengaruh variabel bebas terhadap variabel terikat. Penelitian ini menggunakan intake kelas siswa sebagai sampel, sehingga penelitian eksperimen yang dilakukan adalah penelitian eksperimen kuasi (quasi eksperiment). Quasi eksperimental design mempunyai kelompok kontrol, tetapi tidak dapat berfungsi sepenuhnya untuk mengontrol variabel-variabel luar yang mempengaruhi pelaksanaan eksperimen (Sugiyono, 2009). Rancangan penelitian ini menggunakan pretest-posttest non-equivalent control group design, yaitu desain penelitian eksperimen kuasi yang bertujuan untuk menyelidiki tingkat kesamaan antar kelompok dan motivasi awal berfungsi sebagai kovariat untuk melakukan kontrol secara statistik.

Penelitian ini merupakan penelitian eksperimen yang dilaksanakan pada siswa kelas VIII di SMP Negeri 4 Negara. Sampel penelitian adalah 249 orang siswa yang dipilih dengan teknik random sampling. Beberapa variabel yang dilibatkan dalam penelitian ini adalah variabel independen yaitu (1) strategi ARCS, sedangkan sebagai variabel dependent (terikat) yaitu (2) motivasi belajar. Penelitian ini menyelidiki pengaruh penerapan strategi ARCS dan model pembelajaran direct instruction terhadap variabel terikat yaitu motivasi belajar TIK. Variabel yang merupakan pengendali atau kovariat adalah skor motivasi awal belajar siswa. Instrument pengukuran data yang digunakan dalam penelitian adalah angket motivasi belajar yang digunakan untuk mengumpulkan data tentang motivasi belajar siswa.

$$
\text { Penelitian eksperimen ini }
$$

dilaksanakan melalui beberapa tahapan. Tahap pertama, menyusun kuesioner motivasi belajar, serta sudah mendapatkan pemeriksaan dari dua orang penilai (judges). Tahap kedua, uji coba kuesioner motivasi belajar TIK. Tahap ketiga, memberikan angket motivasi belajar TIK untuk mengetahui motivasi awal. Tahap keempat, tahap pelaksanaan ekperimen yang dilakukan dengan melaksanakan pembelajaran pada siswa kelompok eksperimen dan kelompok kontrol sesuai dengan rencana pembelajaran yang telah disusun. Pembelajaran pada kelompok eksperimen menggunakan strategi pembelajaran ARCS sedangkan pembelajaran pada siswa kelompok kontrol menggunakan model pembelajaran DI. Tahap kelima, dilakukan dengan memberikan angket motivasi belajar TIK baik pada kelompok eksperimen maupun kelompok kontrol untuk mendapatkan data tentang motivasi belajar TIK siswa pada kedua kelompok tersebut.

Data yang diperoleh selanjutnya ditabulasi menjadi dua kelompok data. Keempat kelompok data tersebut yaitu, (1) data motivasi belajar siswa yang mengikuti pembelajaran dengan strategi ARCS, (2) data motivasi belajar siswa yang mengikuti pembelajaran dengan model pembelajaran DI. Data-data tersebut diuji terlebih dahulu normalitas sebaran datanya, uji homogenitas, uji homogenitas matriks varian-kovarian, dan uji kolinieritas. Setelah uji asumsi analisis ini terpenuhi, kemudian pengujian dilakukan dengan menggunakan analisis statistik. 


\section{Hasil Penelitian dan Pembahasan}

Berdasarkan pengujian hipotesis ditemukan terdapat perbedaan motivasi belajar antara siswa yang belajar melalui strategi pembelajaran ARCS dengan siswa yang belajar melalui model pembelajaran langsung pada siswa kelas VIII di SMP Negeri 4 Negara. Berdasarkan hasil analisis dapat diketahui nilai $\mathrm{F}$ hasil perhitungan Mancova sebesar $\mathrm{F}_{\text {hitung }}=$ 248,549 dan angka signifikansi 0,001. Angka signifikansi ini lebih kecil dari 0,05 sehingga $\mathrm{H}_{0}$ ditolak dan $\mathrm{H}_{1}$ diterima. Ratarata motivasi belajar siswa yang di beri perlakuan dengan strategi pembelajaran ARCS lebih besar dari rata-rata kelompok siswa yang diberi perlakuan model pembelajaran langsung,

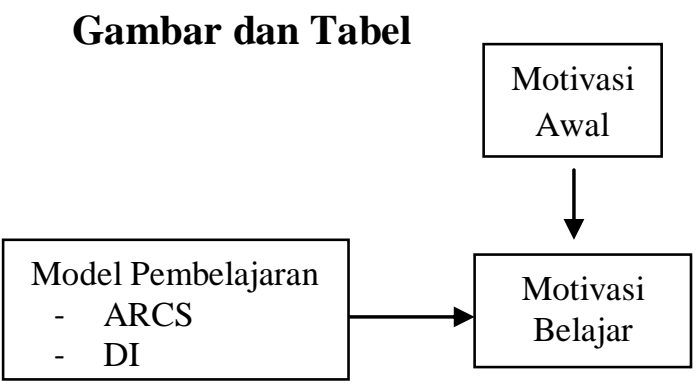

Gambar 1. Hubungan antar variabel penelitian

\section{Kesimpulan dan Saran}

Berdasarkan hasil penelitian dan pembahasan, maka simpulan yang diperoleh adalah terdapat perbedaan motivasi belajar antara siswa yang belajar melalui strategi pembelajaran ARCS dengan siswa yang belajar melalui model pembelajaran langsung pada siswa kelas VIII di SMP Negeri 4 Negara $(\mathrm{F}=$ 248,549; $\alpha=0,001)$. Hasil penelitian menemukan bahwa motivasi belajar antara kelompok siswa yang mendapatkan perlakuan dengan strategi ARCS $(\overline{\mathrm{X}}=124$, 56) lebih baik dibandingkan dengan kelompok siswa yang mendapatkan perlakuan dengan model pembelajaran langsung $(\overline{\mathrm{X}}=113,56)$.

Berdasarkan hasil yang diperoleh diyakini bahwa strategi pembelajaran ARCS secara optimal dapat memberikan dampak positif dalam upaya meningkatkan motivasi belajar siswa.

\section{Daftar Pustaka}

Candiasa, I M. 2004. Statistik multi variat disertai aplikasi dengan SPSS. Singaraja: Unit Penerbitan Universitas Pendidikan Ganesha.

Candiasa, I M. 2010. Statistik univariat dan bivariat disertai aplikasi dengan SPSS. Singaraja: Unit Penerbitan Universitas Pendidikan Ganesha.

Degeng, I N. S. 2001. Landasan dan wawancara kependidikan. Malang: Lembaga Pengembangan dan Pendidikan (LP3) Universitas Negeri Malang.

Depdiknas. 2003. Naskah akademik kajian kebijakan kurikulum mata pelajaran TIK. Jakarta : Departemen Pendidikan Nasional.

Depdiknas. 2005. Peraturan pemerintah RI no. 19 Tahun 2005 tentang standar nasional pendidikan. Jakarta : Departemen Pendidikan Nasional.

Fatimah, N. \& Abdullah, A. A. 2013. Pengaruh strategi motivasi attention, relevance, confidance, satisfaction (arcs) dalam model pembelajaran langsung terhadap hasil belajar siswa pada pokok bahasan listrik dinamis di kelas x sma negeri 18 surabaya. Jurnal Inovasi Pendidikan Fisika. 2(2). 75-77. Tersedia pada http://ejournal.unesa.ac.id/article/ 5157/32/article.pdf. Diakses pada Tanggal 18 November 2013. 
Hamdu, G. \& Agustina, L. 2011. Pengaruh motivasi belajar siswa terhadap prestasi belajar IPA di sekolah dasar. Jurnal Penelitian Pendidikan. 12(1): 90-96. Tersedia pada http://jurnal. upi.edu/file/8-GhullamHamdu1.pdf. Diakses pada Tanggal 18 November 2013.

Keller, J. 1987. Development and use of the arcs model of instructional design. Journal of Instructional Development. 10(3): 2-10. Tersedia pada http://link.springer.com/article/ 10.1007/BF02905780\#page-1.

Diakses pada Tanggal 13 November 2013.

Nugrahini, N P Prita. 2013. Perangkat pembelajaran bidang studi TIK kelas VII, VIII dan IX semester 2 tahun pembelajaran 2012/2013. Daftar Nilai Siswa. (Tidak diterbitkan). SMP Negeri 4 Negara.

Solihatin, E. \& Raharjo. 2007. Cooperative learning. Jakarta: PT. Bumi Aksara.

Sugiyono. 2009. Metode penelitian kuantitatif, kualitatif, dan $R \& D$. Bandung: Alfabeta.

Sulistiyani. 2011. Efektivitas pembelajaran arcs (attention, relevance, confidence, satisfaction) berbantuan alat peraga terhadap peningkatan hasil belajar matematika peserta didik pada pokok bahasan segiempat. Skripsi. (Tidak diterbitkan). Fakultas Tarbiyah Institut Agama Islam Negeri Walisongo. Semarang. Tersedia pada http://library.walisongo.ac.id/digilib /files/disk1/118/jtptiain-gdlsulistiyan-5886-1073511072.pdf. Diakses pada Tanggal 18 November 2013.
Trianto. 2007. Model-model pembelajaran inovatif berorientasi konstruktivistik. Jakarta: Prestasi Pustaka.

Winaya, I M. A. 2013. Pengaruh pembelajaran berbasis arcs (attention, relevance, confidence, and satisfaction) terhadap hasil belajar dengan kovariabel motivasi belajar siswa pada pembelajaran ips di kelas iv sd chis denpasar. Tesis. (tidak diterbitkan). Program Studi Pendidikan Dasar Program Pascasarjana Universitas Pendidikan Ganesha. Singaraja.

Wena, M. 2009. Strategi pembelajaran inovatif kontemporer. Jakarta Timur: PT 